\title{
PENERAPAN METODE QUANTUM: BAGAIMANA SISWA MENULIS TEKS NEGOSIASI?
}

\author{
Aini Nur Muthowiatin, Sutrimah, Cahyo Hasanudin \\ aininurmuthowiatin@gmail.com, sutrimah@yahoo.com, \\ cahyo.hasanudin@ikippgribojonegoro.ac.id \\ IKIP PGRI Bojonegoro
}

*Diterima: 3 Juli 2020, Disetujui: 06 Agustus 2020

\begin{abstract}
This study aimed to investigate the negotiation text written by tenth grade students of MA almunawar using quantum learning method. This study was qualitative research in form of case study in which twenty five students acted as the research subjects. Seven students were chosen to be interviewed because their negotiation texts were appropriate with the indicators. Techniques in colleting data were observation, test, interview, and documentation. The data was validated by using triangulations of data source and method. Technique in analysing data used content analysis method that was started from data reduction, data presentation, drawing conclusion and verification. The result of study showed that the negotiation texts written by the tenth grade students of MA almunawar were in line with Rahman's theory. The conclusion stated that quantum was very appropriate to be implemented in the classroom learning. It showed its novelty in the learning process and encouraged the students to learn the materials.
\end{abstract}

Keywords: quantum learning, negotiation text, students

\begin{abstract}
Abstrak
Penelitian ini bertujuan untuk mengetahui bentuk teks negosiasi yang ditulis oleh siswa kelas X MA Al-Munawwar Kunci Dander Bojonegoro dengan menggunakan metode pembelajaran quantum. Penelitian ini adalah penelitian kualitatif dengan menggunakan pendekatan studii kasus dengan jumlah subjek 25 siswa. Dari 25 siswa kemudian peneliti mengambil 7 siswa untuk diwawancarai dengan alasan teks negosiasinya sesuai dengan indikator. Teknik pengumpulan data menggunakan observasi, metode tes, wawancara, dan dokumentasi. Data divaliditaskan dengan menggunakan triangulasi sumber data dan triangulasi metode. Teknik analisis data menggunakan metode contact analysis yang dimulai dari 1). reduksi data, 2). penyajian data, 3). penarikan simpulan dan verifikasi. Hasil penelitian menunjukkan bahwa keterampilan menulis teks negosiasi yang ditulis oleh siswa kelas X MA Al-Munawwar Kunci Dander Bojonegoro sesuai dengan teori Rahman dengan baik. Simpulan pada penelitian ini yaitu pembelajaran quantum sangat tepat digunakan dalam pembelajaran di kelas. Pembelajaran quantum memberikan pembaruan dalam proses pembelajaran serta siswa secara aktif terdorong mempelajari materi pembelajaran.

Kata Kunci: quantum learning, teks negosiasi, siswa
\end{abstract}

\section{PENDAHULUAN}

Menulis merupakan salah satu aktivitas yang sangat penting yang dapat dilakukan dengan memanfaatkan berbagai macam media. Menulis adalah gambaran isi hati pengarang yang dituangkan dalam bentuk tulisan (Pratiwi, 2018:2). Menulis disebut juga sebagai suatu aktivitas yang memerlukan kemampuan berpikir (Septiaji, 2017:68). Menurut Rahman (2017:34) menulis adalah salah satu keterampilan 
berbahasa yang digunakan untuk berhubungan secara tidak langsung. Menulis dapat diartikan sebagai salah satu cara untuk menuangkan kreativitas, menemukan ide baru, dan perantara untuk mengembangkan prestasi sejak dini (Hidayah, Darmuki, dan Hasanudin, 2019:310)

Salah satu bentuk pembelajaran menulis yaitu menulis teks negosiasi. Menulis teks negosiasi terdapat pada kurikulum 2013 kompetensi dasar 4.11 yaitu mengontruksikan teks negosiasi dengan memperhatikan isi, struktur (bentuk orientasi, bentuk permintaan, bentuk pemenuhan, bentuk penawaran, bentuk persetujuan, bentuk pembelian, bentuk penutup).

Berpijak dari hasil wawancara dan observasi dalam pembelajaran bahasa Indonesia khususnya materi menulis teks negosiasi masih ditemukan beberapa kendala. Guru masih menggunakan metode konvensional (ceramah) dalam menyampaikan materi pembelajaran. Guru hanya menjelaskan struktur serta karakteristik dari teks negosiasi. Pendapat ini sejalan dengan Patonah, Syahrullah, Firmansyah, dan Fauziya (2018:808) yang mengemukakan bahwa siswa masih belum sepenuhnya mengerti teks yang dipelajari, sehingga masih kebingungan dalam menentukan struktur dan karakteristik teks negosiasi. Kendala lainnya juga dialami oleh siswa. Siswa kurang tertarik dalam mengikuti kegiatan menulis sehingga kemampuan menulis siswa kurang maksimal. Menurut Osmimi (2018:160) terdapat kendala-kendala yang sering dialami siswa saat proses kegiatan belajar mengajar berlangsung. Kendala-kendala tersebut yaitu, minat siswa yang masih rendah dalam menulis teks negosiasi, siswa belum mampu mengungkapkan ide-ide secara logis, siswa masih kebingungan dalam menulis teks negosiasi karena kurangnya pemahaman tentang struktur teks negoisasi.

Berdasarkan permasalahan tersebut, selanjutnya dicarikan solusi dengan menerapan metode quantum. Metode quantum merupakan salah satu model pembelajaran yang di dalamnya terdapat petunjuk dan strategi sehingga dapat mempertajam daya ingat siswa (Puspaningrum, Mahartika, dan Supriadi, 2015:343). Menurut Ahsin (2016:161) metode quantum adalah salah satu metode pembelajaran yang memotivasi siswa dalam belajar. Metode quantum dapat diartikan sebagai salah satu model pembelajaran yang menciptakan perilaku siswa yang berkarakter seperti jujur, disiplin, dan bertanggung jawab (Tirtoni, 2015:162).

Hasil penelitian yang dilakukan oleh Mahananingtyas (2016:17-25) menggunakan metode quantum learning dapat meningkatkan kepercayaan diri serta hasil belajar siswa. Sedangkan penelitian yang dilakukan oleh Tarmuji (2009:248267) mengenai pembelajaran memproduksi teks negosiasi siswa semakin baik dan mengalami peningkatan yang signifikan. Penelitian yang dilakukan oleh Hasanudin dan Asror (2017:150-159) menggunakan model pembelajaran quantum learning sangat membantu siswa dalam meningkatkan keterampilan membaca nyaring baik suku kata, kata, dan kalimat sederhana serta lafal dan intonasi yang tepat. Berdasarkan hasil penelitian tersebut dapat disintesiskan bahwa pembelajaran quantum merupakan metode pembelajaran inovatif yang dapat meningkatkan minat belajar siswa sehingga penelitian ini penting dilakukan karena pembelajaran quantum jika diterapkan dalam pembelajaran menulis teks negosiasi akan mempermudah siswa dalam menerima materi pembelajaran dan dapat menulis teks negosiasi sesuai indikator yang telah ditentukan.

Pembelajaran menggunakan metode quantum ini diharapkan dapat meningkatkan semangat dan kepercayaan diri siswa dalam belajar. Kegiatan belajar mengajar yang menggunakan metode quantum jika diterapkan dalam pembelajaran menulis teks negosiasi akan memudahkan siswa dalam pembelajaran. 


\section{KAJIAN LITERATUR}

Berikut teori-teori yang relevan dengan penelitian yang meliputi, teks negosiaisi, metode pembelajaran quantum, pembelajaran menulis teks negosiasi dengan menggunakan metode quantum.

\section{Teks Negosiasi}

Negosiasi adalah bentuk interaksi sosial untuk mendapatkan kesepakatan yang melibatkan dua pihak atau lebih (Istijanto, 2007:21). Menurut Wibowo (2011:4) negosiasi merupakan perbedaan kepentingan antara dua orang atau kelompok dengan adanya tawar menawar. Melalui teks negosiasi dapat menjadikan siswa mempunyai sikap toleransi yang tinggi, membangun kesadaran akan lingkungan sekitarnya, serta mengetahui hubungan timbal balik sosial (Hasanudin, Fitrianingsih, dan Saddhono, 2019:559).

Menurut Rahman (2018:15) struktur teks negosiasi sebagai berikut: (1) Bentuk orientasi merupakan pembukaan atau awalan percakapan, (2) Bentuk permintaan merupakan pihak yang ingin tahu menanyakan suatu barang yang dibutuhkan, (3) Bentuk pemenuhan merupakan pihak yang terkait memberikan informasi terhadap pihak yang membutuhkan, (4) Bentuk penawaran merupakan proses tawar menawar agar mendapatkan kesepakatan yang sesuai dan saling menguntungkan, (5) Bentuk persetujuan merupakan hasil penawaran yang telah disepakati kedua belah pihak, (6) Bentuk pembelian merupakan terjadinya transaksi antara penjual dan pembeli, (7) Bentuk penutup merupakan akhir dari sebuah percakapan kedua belah pihak yang telah menyelesaikan kesepakatan.

\section{Metode pembelajaran Quantum}

Metode pembelajaran quantum adalah suatu metode pembelajaran yang menciptakan kegiatan belajar mengajar menjadi nyaman dan menggembirakan, sehingga siswa lebih mudah untuk menemukan pengetahuan baru (Mahananingtyas, 2016:17).

Metode pembelajaran quantum memiliki beberapa manfaat yaitu dapat memberikan sikap positif, memotivasi siswa, memberikan kemampuan belajar sepanjang hayat, serta membangkitkan kepercayaan diri siswa (Mayangsari dan Umroh, 2014:79). Metode quantum memiliki istilah TANDUR, yaitu singkatan dari (1) Tumbuhkan artinya menumbuhkan minat siswa untuk belajar (2) Alami artinya menciptakan atau memberikan pengalaman langsung yang mudah dipahami oleh siswa, (3) Namai artinya menyajikan kata kunci, rancangan, model, dan rumus, (4) Demonstrasikan artinya memberikan kesempatan kepada siswa untuk memperlihatkan kemampuannya, (5) Ulangi artinya menunjukkan cara-cara mengulas materi dan mempertegas penjelasan, (6) Rayakan artinya memberikan apresiasi kepada siswa sebagai salah satu bentuk respon yang sepadan (Djalil, 2015:178).

Pembelajaran Menulis Teks Negosiasi dengan Menggunakan Metode Quantum

Penerapan metode quantum pada keterampilan menulis teks negosiasi dikembangkan dari teori Nata (2012:39) dapat dijelaskan dengan langkah-langkah pembelajaran sebagai berikut. 1). T (tumbuhkan) Siswa diajak mengaitkan materi pembelajaran yang sudah dipelajari sebelumnya dengan materi yang akan dipelajari, 2). A (alami) Guru menjelaskan kepada siswa agar siswa memahami materi teks negosiasi, 3). N (namai) Siswa memahami penjelasan guru mengenai materi teks negosiasi, 4). D (demonstrasikan) Siswa menyimak penjelasan guru cara menulis teks negosiasi. Guru memberikan contoh cara menulis teks negosiasi, 5). U (ulangi) Siswa secara individu menulis teks negosiasi. Guru mengamati siswa dan 
mengarahkan, 6). R (rayakan) Siswa bersama dengan guru memberikan tepuk tangan kepada siswa yang mendapatkan nilai bagus.

\section{METODE PENELITIAN}

Penelitian ini merupakan penelitian kualitatif dengan menggunakan jenis penelitian studi kasus. Penelitian kualitatif adalah penelitian yang dilakukan untuk memahami tentang apa yang dialami oleh subjek penelitian (Moleong, 2015:6). Data yang diperoleh pada penelitian ini adalah bagaimana struktur teks negosiasi yang terdiri dari bentuk orientasi, bentuk permintaan, bentuk pemenuhan, bentuk penawaran, bentuk persetujuan, bentuk pembelian, bentuk penutup yang ditulis oleh siswa kelas X MA Al-Munawwar Kunci Dander Bojonegoro ketika diajar menggunakan metode quantum. Penelitian ini dilakukan pada bulan Maret-Mei 2020. Subjek pada penelitian ini berjumlah 25 siswa. Dari 25 siswa diambil 7 siswa yang dijadikan subjek dalam penelitian untuk diwawancarai dengan alasan keterampilan menulis teks negosiasinya bagus dan sesuai indikator menurut teori Rahman (2018:15). Sumber data dalam penelitian ini adalah siswa kelas X MA AlMunawwar Kunci Dander Bojonegoro. Data yang diperoleh dari siswa berwujud hasil tes menulis teks negosiasi dan wawancara dengan siswa tersebut.

Teknik pengumpulan data melalui observasi, tes, wawancara, dan dokumtasi. Teknik analisis data pada penelitian ini merujuk pada teori Miles and Huberman dalam Sugiyono (2015:91) yang meliputi tiga analisis data yang terdiri dari reduksi data, penyajian data, dan penarikan simpulan. Dalam penelitian ini menggunakan triangulasi sumber data dan triangulasi metode.Triangulasi sumber data dilakukan dengan membandingkan data hasil tes menulis teks negosiasi dan wawancara. Pada triangulasi metode dilakukan dengan cara peneliti menggunakan lebih dari satu metode pengumpulan data untuk mendapatkan data yang sama. Peneliti melakukan tes menulis teks negosiasi kemudian melakukan klarifikasi dengan hasil wawancara.

\section{HASIL PENELITIAN DAN PEMBAHASAN} Hasil

Hasil teks negosiasi yang ditulis siswa sebagai berikut.

Berlandasan pada struktur menulis teks negosiasi yang dikemukakan oleh Rahman (2018:15). Struktur teks negosiasi yang dituis oleh siswa kelas X MA AlMunawwar Kunci Dander Bojonegoro sudah mengacu pada struktur teks negosiasi sesuai dengan teori Rahman dengan benar. Berikut teks negosiasi yang ditulis oleh siswa.

Struktur teks negosiasi yang pertama yaitu bentuk orientasi.Berikut ini adalah bentuk orientasi teks negosiasi yang ditulis oleh siswa.

$$
\begin{array}{|c|}
\hline \text { Penjual: Selamat malam, bu rina lelihotanya } \\
\text { leole bingung. } \\
\text { Pembeli: lya nih pale, bingung mau beli moleanon } \\
\text { apa untule ueluarga. } \\
\text { penjual: lebetulan nih ada sate bu, baru mortang } \\
\text { enale lo } \\
\text { pembeli: oh, lya juga }
\end{array}
$$

Gambar 1. Bentuk Orientasi Teks Negosiasi 
Pada lembar tes menulis teks negosiasi, siswa membuat bentuk orientasi dengan melibatkan tokoh penjual dan pembeli. Bentuk orientasi ini berisi tentang seorang pembeli yang sedang bingung membeli makanan.Berdasarkan teks negosiasi yang ditulis oleh siswa, kita dapat mengetahui bahwa siswa mampu membuat bentuk orientasi dengan baik dan sesuai dengan struktur teks negosiasi.Ketika peneliti mengajukan pertanyaan, mengapa dia menulis bentuk orientasi seperti itu, siswa menjelaskan bahwa konsep tersebut muncul di benaknya, sebab kejadian itu pernah dialami saat bingung membeli jajan di kantin .Hal tersebut dapat ditunjukkan pada kutipan wawancara berikut.

$P \quad$ : "Apakah kamu sudah memahami struktur teks negosiasi?"

S1 : "Sudah, Bu."

$P \quad$ : "Kamu sudah paham bentuk orientasi pada teks negosiasi?"

S1 : "Sudah, Bu."

$P \quad$ : "Mengapa kamu membuat bentuk orientasi dengan mengangkat penjual dan pembeli sebagai tokoh percakapan?"

S1 : "Karena kejadian itu pernah saya alami sendiri saat membeli jajan di kantin, pada percakapan antara kedua pihak tersebut dapat disusun menjadi pembuka dalam teks negosiasi yang menghasilkan sebuah persetujuan."

Bentuk orientasi teks negosiasi yang ditulis oleh subjek 1 tentang seorang pembeli yang sedang bingung membeli makanan. Bentuk orientasi pada teks negosiasi sudah sesuai dengan bentuk orientasi yang diungkapkan oleh Rahman. Rahman (2018:15) menjelaskan bahwa orientasi yang baik adalah orientasi yang mengungkapkan permasalahan yang akan dinegosiasikan.

Struktur teks negosiasi yang kedua yaitu bentuk permintaan.Berikut ini adalah bentuk permintaan teks negosiasi yang ditulis oleh siswa.

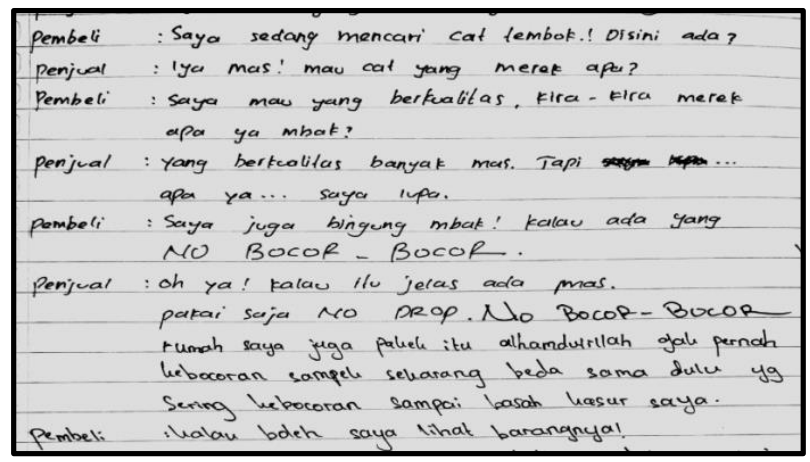

Gambar. 2 Bentuk Permintaan Teks Negosiasi

Pada lembar tes menulis teks negosiasi. Siswa membuat bentuk permintaan dengan melibatkan tokoh penjual dan pembeli. Bentuk permintaan ini berisi tentang seorang pembeli yang sedang mencari cat tembok. Berdasarkan teks negosiasi yang ditulis oleh siswa, dapat diketahui bahwa siswa mampu membuat bentuk permintaan dengan baik dan benar. Ide tersebut datang karena sering melihat iklan di televisi. Hal ini dapat ditunjukkan pada kutipan wawancara berikut.

$P$ : "Apakah kamu sudah memahami bagian bentuk permintaan pada teks negosiasi?"

S2 : "Sudah, Bu."

$P \quad$ : "Mengapa kamu membuat bentuk permintaan seperti itu?"

S2 : "Karena saya sering melihat iklan di televisi bu, sehingga saya terinspirasi untuk membuat itu."

Bentuk permintaan pada teks negosiasi yang dibuat oleh S2 sudah sesuai dengan bentuk permintaan yang diungkapkan oleh Rahman. Rahman (2018:16)

Tabasa: Jurnal Bahasa, Sastra Indonesia, dan Pengajarannya

Vol. 1, No. 1, Juni 2020 
menjelaskan bahwa bentuk permintaan yang baik adalah permintaan yang berisi pernyataan negosiator pertama untuk meminta, mengajak, mendorong negosiator kedua melakukan sesuatu yang sesuai dengan keinginannya.

Struktur teks negosiasi yang ketiga yaitu bentuk pemenuhan.Berikut ini adalah bentuk pemenuhan teks negosiasi yang ditulis oleh siswa.

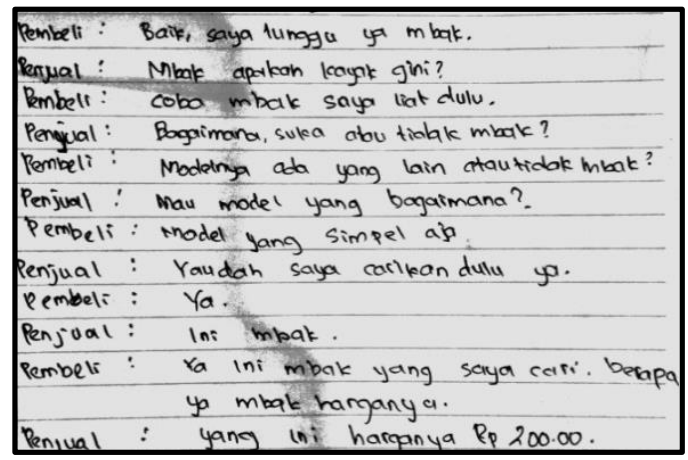

Gambar. 3 Bentuk Pemenuhan Teks Negosiasi

Pada lembar tes menulis teks negosiasi. Siswa membuat bentuk pemenuhan dengan melibatkan tokoh penjual dan pembeli. Bentuk pemenuhan ini berisi tentang seorang penjual yang memenuhi keinginan pembeli yang sedang mencari sepatu. Berdasarkan teks negosiasi yang ditulis oleh siswa, dapat diketahui bahwa siswa mampu membuat bentuk pemenuhan dengan baik dan benar. Alasan siswa menulis teks tersebut, bahwa setiap penjual pasti memberikan apa yang mereka jual untuk memenuhi kebutuhan pembeli. Hal ini dapat ditunjukkan pada kutipan wawancara berikut.

$P \quad$ : "Apakah kamu sudah memahami bentuk pemenuhan pada teks negosiasi?"

S3 : "Sudah, Bu"

$P \quad$ : "Mengapa kamu membuat bentuk pemenuhan seperti itu?"

S3 : "Karena setiap penjual pasti memberikan apa yang mereka jual untuk memenuhi kebutuhan pembeli"

Bentuk pemenuhan pada teks negosiasi yang dibuat oleh S3 sudah sesuai dengan bentuk pemenuhan yang diungkapkan oleh Rahman. Rahman (2018:16) menjelaskan bahwa bentuk pemenuhan yang baik ialah pihak terkait memberitahu mengenai barang atau obyek agar orang yang diajak interaksi oleh pihak tersebut menjadi lebih paham.

Struktur teks negosiasi yang keempat yaitu bentuk penawaran.Berikut ini adalah bentuk penawaran teks negosiasi yang ditulis oleh siswa.

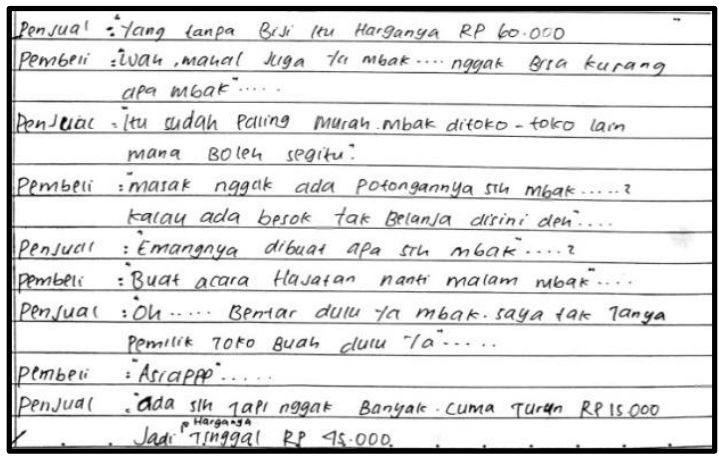

Gambar. 4 bentuk Penawaran Teks Negosiasi 
Pada lembar tes menulis teks negosiasi. Siswa membuat bentuk penawaran dengan melibatkan tokoh penjual dan pembeli. Tokoh pembeli meminta penawaran kepada penjual untuk mengurangi harga buah semangka yang akan dibeli. Berdasarkan teks negosiasi yang ditulis oleh siswa, dapat diketahui bahwa siswa mampu menulis bentuk penawaran sesuai indikator teks negosiasi. Ide bentuk penawaran muncul ketika siswa tersebut melihat seorang pembeli sedang menawar di toko tetangganya. Hal ini dapat ditunjukkan pada kutipan wawancara berikut.

$P$ : "Apakah kamu sudah memahami bagian bentuk penawaran pada teks negosiasi?"

S4: "Sudah, Bu."

$P \quad$ : "Mengapa kamu menulis bentuk penawaran seperti itu?"

S4 : "Karena saya mendapatkan ide itu ketika saya melihat seorang pembeli sedang menawar di toko tetangga saya, Bu."

Bentuk penawaran pada teks negosiasi yang dibuat oleh S4 sudah sesuai dengan bentuk penawaran yang diungkapkan oleh Rahman. Rahman (2018:16) menjelaskan bahwa bentuk penawaran yang baik adalah penawaran yang berisi sejumlah pernyataan argumentasi beserta alasannya pada penawaran dan penolakan yang diajukan.

Struktur teks negosiasi yang kelima yaitu bentuk bentuk persetujuan. Berikut ini adalah bentuk persetujuan teks negosiasi yang ditulis oleh siswa.

$$
\begin{array}{|}
\text { Icha: "Saya hanya punya uang } 18 \text { juta, hagaimana } \\
\text { Sherly: "Ya cudah mbak, Saya pinjam dulu llame } \\
\text { itu, kelurangannya saya akan cari lagi, 8an } \\
\text { Jika usaha saya sedah lancar "saya akan } \\
\text { mengembalikan uang itu" } \\
\text { Icha "Iyn, dengan senang hati saya meminjamlean } \\
\text { uang ini dengan anda" }
\end{array}
$$

Gambar. 5 bentuk persetujuan Teks Negosiasi

Pada lembar tes menulis teks negosiasi. Siswa membuat bentuk persetujuan dengan melibatkan tokoh Sherly dan Icha. Kesepakatan ini tentang persetujuan Icha meminjamkan uang kepada Sherly. Persetujuan yang ditulis siswa menghasilkan kesepakatan yang tidak merugikan kedua belah pihak. Berdasarkan teks negosiasi yang ditulis oleh siswa, dapat diketahui bahwa siswa mampu menulis bentuk persetujuan dengan baik sesuai struktur teks negosiasi. Alasan siswa menulis tersebut adalah kejadian demikian sering terjadi dirumahnya. Hal ini dapat ditunjukkan pada kutipan wawancara berikut.

$P \quad$ : "Kamu sudah memahami struktur teks negosiasi?"

S5 : "Sudah, Bu."

$P \quad$ : "Apakah kamu sudah memahami bagian bentuk persetujuan pada teks negosiasi?"

S5 : "Sudah, Bu."

$P \quad$ : "Mengapa kamu menulis bentuk persetujuan seperti itu?"

S5 : "Karena kejadian itu sering terjadi dirumah saya sendiri, Bu. Sehingga saya mempunyai ide mengangkat permasalahan ini untuk dijadikan topik teks negosiasi."

Bentuk persetujuan pada teks negosiasi yang dibuat oleh S5 sudah sesuai dengan bentuk persetujuan yang diungkapkan oleh Rahman. Rahman (2018:16) menjelaskan bahwa bentuk persetujuan yang baik adalah kesepakatan yang mengungkapkan pesetujuan atau ketidaksetujuan antara kedua belah pihak.

Tabasa: Jurnal Bahasa, Sastra Indonesia, dan Pengajarannya

Vol. 1, No. 1, Juni 2020 
Struktur teks negosiasi yang keenam yaitu bentuk bentuk pembelian. Berikut ini adalah bentuk pembelian teks negosiasi yang ditulis oleh siswa.

Permbeli : jadi lss mbak?
Jinjual: Iya, buk.. !
Pembeli , Ini mbak uangnya 160
Periual : Ini buk kembaliannya (5000)!

Gambar. 6 bentuk pembelian Teks Negosiasi

Pada lembar tes menulis teks negosiasi. Siswa membuat bentuk pembelian dengan melibatkan tokoh penjual dan pembeli.Kedua tokoh ini bernegosiasi untuk melakukan pembelian piring. Sehingga pihak penjual deal terhadap harga yang diminta oleh pembeli dan tidak ada unsur paksaan. Berdasarkan teks negosiasi yang ditulis oleh siswa, dapat diketahui bahwa siswa mampu menulis bentuk pembelian dengan baik sesuai struktur teks negosiasi.Alasan siswa menulis tek tersebut karena pernah menjumpai hal itu di pasar. Hal ini dapat ditunjukkan pada kutipan wawancara berikut.

$P \quad$ : "Kamu sudah memahami struktur teks negosiasi?"

S6 : "Sudah, Bu."

$P$ : "Apakah kamu sudah memahami bagian bentuk pembelian pada teks negosiasi?"

S6 : "Sudah, Bu."

$P \quad$ : "Mengapa kamu menulis bentuk pembelian seperti itu?"

S6 : "Saya pernah menjumpai hal seperti itu ketika diajak ibu ke pasar, oleh karena itu saya bisa menulis pembelian pada teks negosiasi."

Bentuk pembelian pada teks negosiasi yang dibuat oleh S6 sudah sesuai dengan bentuk pembelian yang diungkapkan oleh Rahman. Rahman (2018:16) menjelaskan bahwa bentuk pembelian ialah terjadinya transaksi jual beli antara masing-masing pihak terkait.

Struktur teks negosiasi yang ketujuh yaitu bentuk bentuk penutup. Berikut ini adalah bentuk penutup teks negosiasi yang ditulis oleh siswa.

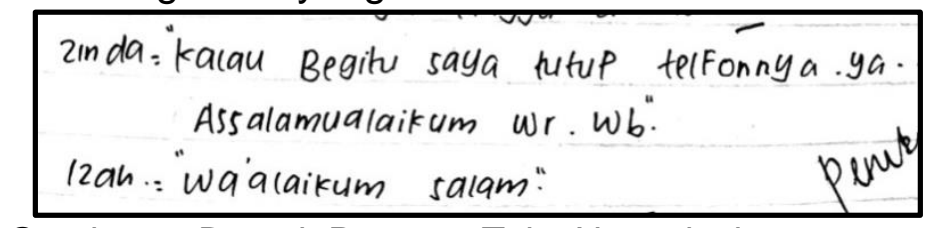

Gambar. 7 Bentuk Penutup Teks Negosiasi

Pada lembar tes menulis teks negosiasi. Siswa membuat bentuk penutup dengan melibatkan tokoh Zinda dan Izah. Siswa membuat bentuk penutup untuk mengakhiri sebuah percakapan. Setelah melakukan negosiasi maka diakhiri dengan ucapan salam. Berdasarkan teks negosiasi yang ditulis oleh siswa, dapat diketahui bahwa siswa mampu menulis bentuk penutup dengan baik sesuai struktur teks negosiasi. Alasan siswa menulis teks tersebut, bahwa untuk menutup percakapan atau pertemuan alangkah baiknya dengan mengucapkan salam. Hal ini dapat ditunjukkan pada kutipan wawancara berikut.

$P \quad$ : "Mengapa kamu menulis bentuk penutup seperti itu?" 
: "untuk menutup percakapan atau pertemuan alangkah baiknya dengan mengucapkan salam."

Bentuk penutup pada teks negosiasi yang dibuat oleh S7 sudah sesuai dengan bentuk pembelian yang diungkapkan oleh Rahman. Rahman (2018:16) menjelaskan bahwa bentuk penutup ialah mengakhiri sebuah percakapan antara kedua belah pihak untuk menyelesaikan proses interaksi dalam negosiasi.

Merujuk pada struktur menulis teks negosiasi yang dikemukakan oleh Rahman. Struktur teks negosiasi yang ditulis oleh siswa kelas X MA Al-Munawwar Kunci Dander Bojonegoro, sudah mengacu pada struktur teks negosiasi sesuai dengan teori Rahman dengan benar.

Pada bentuk orientasi teks negosiasi. Siswa dapat menulis dengan baik dan benar, Siswa terinspirasi membuat teks negosiasi dengan topik tawar menawar penjual sate dan pembeli.Dia menjelaskan bahwa konsep itu muncul dibenaknya ketika kejadian itu pernah dialami dirinya sendiri saat bingung membeli jajan di kantin. Orientasi merupakan bagian pembuka yang berisi pengenalan baik pihak pengajuan atau penawar (Sutarno, 2019:72).

Pada bentuk permintaan teks negosiasi. Siswa dapat menulis dengan baik dan benar. Bentuk permintaan yang ditulis oleh siswa mencerminkan ada salah satu pihak mengajukan sebuah bentuk permintaan. Bentuk permintaan ini berisi tentang seorang pembeli yang sedang mencari cat tembok. Permintaan diajukan oleh pembeli kepada penjual untuk memberikan barang yang dibutuhkan. Bentuk permintaan merupakan bagian teks negosiasi yang berisi tentang pengajuan oleh salah satu pihak (Mahsun, 2014:22).

Pada bentuk pemenuhan teks negosiasi. Siswa dapat menulis dengan baik dan benar. Bentuk pemenuhan yang ditulis oleh siswa memcerminkan ada salah satu pihak mengajukan sebuah bentuk pemenuhan. Bentuk pemenuhan ini berisi tentang seorang penjual yang memenuhi keinginan pembeli yang sedang mencari sepatu. Siswa menjelaskan bahwa setiap penjual pasti memberikan apa yang mereka jual untuk memenuhi kebutuhan pembeli. Bentuk pemenuhan merupakan hasil negosiasi yang bergantung pada itikad baik masing-masing pihak (Riyanto, 2018:198).

Pada bentuk penawaran teks negosiasi.Siswa dapat menulis dengan baik dan benar. Siswa menulis bentuk penawaran berdasarkan kondisi permasalahan yang diangkat sebagai topik penawaran terjadi disekitar lingkungannya. Permasalahan yang dituliskan melibatkan seorang pembeli yang meminta penawaran kepada penjual mengenai pemotongan harga semangka yang akan dibeli. Penawaran merupakan bagian dari teks negosiasi yang berisi tentang proses terjadinya tawarmenawar antara kedua belah pihak dengan mengajukan beberapa usulan hingga terbentuknya kesepakatan yang akan menguntungkan kedua belah pihak (Osmimi, 2018:162).

Pada bentuk persetujuan teks negosiasi. Siswa menulis bagian bentuk persetujuan berdasarkan permasalahan yang terjadi di rumahnya. Bentuk persetujuan ini tentang Icha yang meminjamkan uang kepada Sherly. Persetujuan yang ditulis siswa menghasilkan kesepakatan yang tidak merugikan kedua belah pihak. Bentuk persetujuan merupakan bagian dari teks negosiasi yang berupa kesepakatan atau hasil penawaran kedua belah pihak, baik berupa kesetujuan atau ketidaksetujuan (Kosasih, 2014:40).

Pada bentuk pembelian teks negosiasi. Siswa menulis bagian bentuk pembelian berdasarkan sering menjumpai di pasar. Bentuk pembelian ini mengenai negosiasi untuk melakukan pembelian piring. Sehingga pihak penjual deal terhadap

Tabasa: Jurnal Bahasa, Sastra Indonesia, dan Pengajarannya

Vol. 1, No. 1, Juni 2020 
harga yang diminta oleh pembeli dan tidak ada unsur paksaan. Bentuk pembelian merupakan bagian dari teks negosiasi yang berupa transaksi menggunakan syarat tertentu (Risdiana, 2016:174).

Pada bentuk penutup teks negosiasi. Siswa membuat bentuk penutup untuk mengakhiri sebuah percakapan. Setelah melakukan negosiasi maka diakhiri dengan ucapan salam. Siswa menjelaskan bahwa untuk menutup percakapan atau pertemuan alangkah baiknya dengan mengucapkan salam. Bentuk penutup merupakan bagian dari teks negosiasi yang berupa ucapan terimakasih atas selesainya proses negosiasi (Nabillah, 2020:206).

Kemampuan siswa kelas X MA Al-Munawwar Kunci Dander Bojonegoro dalam menulis teks negosiasi sesuai dengan struktur teks negosiasi. Hal ini menunjukkan bahwa model pembelajaran dengan menggunakan metode quantum cocok diterapkan pada kompetensi dasar 4.11. Penerapan model pembelajaran dengan menggunakan metode quantum memberikan pembaruan dalam proses pembelajaran serta siswa secara aktif terdorong mempelajari materi pembelajaran.

\section{PENUTUP}

Bentuk teks negosiasi yang ditulis oleh siswa kelas X MA Al-Munawwar Kunci Dander Bojonegoro pada pembelajaran dengan menerapkan metode quantum sudah mengacu pada struktur teks negosiasi sesuai teori Rahman. Pada bentuk orientasi siswa terinspirasi membuat teks negosiasi dengan topik tawar menawar penjual sate dan pembeli. Pada bentuk permintaan ini berisi tentang seorang pembeli yang sedang mencari cat tembok. Permintaan diajukan oleh pembeli kepada penjual untuk memberikan barang yang dibutuhkan. Pada bentuk pemenuhan teks negosiasi mencerminkan ada salah satu pihak yang mengajukan sebuah bentuk pemenuhan. Bentuk pemenuhan ini berisi tentang seorang penjual yang memenuhi keinginan pembeli yang sedang mencari sepatu. Pada bentuk penawaran teks negosiasi permasalahan yang dituliskan melibatkan seorang pembeli yang meminta penawaran kepada penjual mengenai pemotongan harga semangka yang akan dibeli. Pada bentuk persetujuan teks negosiasi ini berisi tentang peminjaman uang. Persetujuan yang ditulis siswa menghasilkan kesepakatan yang tidak merugikan kedua belah pihak. Pada bentuk pembelian teks negosiasi ini mengenai negosiasi untuk melakukan pembelian piring. Sehingga pihak penjual deal terhadap harga yang diminta oleh pembeli dan tidak ada unsur paksaan. Pada bentuk penutup teks negosiasi siswa membuat bentuk penutup untuk mengakhiri sebuah percakapan. Setelah melakukan negosiasi maka diakhiri dengan ucapan salam.

Berdasarkan simpulan di atas, peneliti dapat mengajukan saran-saran sebagai berikut: Guru sebaiknya memanfaatkan penggunaan metode quantum untuk menumbuhkan kreativitas siswa. Siswa sebaiknya dalam pembelajaran keterampilan menulis teks negosiasi hendaknya menggunakan metode quantum yang mampu memunculkan daya kreativitas mereka. Pembaca sebaiknya lebih memahami penerapan metode pembelajaran quantum pada keterampilan menulis teks negosiasi.Peneliti yang lain sebaiknya menjadikan hasil penelitian ini sebagai pijakan untuk melakukan penelitian yang semakin intensif terkait dengan metode pembelajaran.

\section{DAFTAR PUSTAKA}

Ahsin, M.N. (2016). Peningkatan kterampilan menulis karangan narasi dengan menggunakan media Audiovisualdan metode quantum learning. Jurnal refleksi 
edukatika,

$6(2)$,

158-171.

Retrieved

from

https://jurnal.umk.ac.id/index.php/RE/article/view/607/0

Djalil, B. (2015). Paradigma, prinsip, dan aplikasi quantum learning dan quantum teaching dalam pembelajaran. Jurnal lentera, 1(2), 172-180. Retrieved from https://pdfs.semanticscholar.org/3c82/0b5072dd80f48b7492a9e924544c648d4 c00.pdf

Hasanudin, C. dan Asror, A. G. (2017). Evektivitas model pembelajaran quantum learning dengan media aplikasi bamboomedia bmgames apps terhadap keterampilan membaca permulaan pada siswa kelas I MI se-kecamatan Kedungadem. Pedagogika, 6(2), 150-159. Retrieved from http://ojs.umsida.ac.id/index.php/pedagogia/index

Hasanudin, C., Fitrianingsih, A., dan Saddhono, K. (2019). How the student's negotiation text in collaborative learning og flipped classroom and a cyberlink power director media apps. Journal homepage, 24(6), 559-567. Retrieved from http://iieta.org/journals/isi

Hidayah, R. N., Darmuki, A., dan Hasanudin, C. (2019). Peningkatan keterampilan menulis puisi dengan menggunakan metode quantum learning dan media video pada siswa kelas X IPA I SMA Negeri 2 Blora tahun ajaran 2018/2019. Jurnal linguistik, sastra, dan pendidikan, 4(1), 309-320. Retrieved from http://ejournal.unwmataram.ac.id/trendi

Istijanto. (2007). Seni menaklukkan penjual dengan negosiasi. Jakarta: Gramedia Pustaka Utama.

Kosasih, E. (2014). Jenis-jenis teks drama dalam mata pelajaran bahasa Indonesia $S M A / M A / S M K$. Bandung: Yrama widya.

Mahananingtyas, E. (2016). Metode quantum learning untuk meningkatkan efikasi diri dan hasil belajar IPS siswa kelas $\mathrm{V}$ sekolah dasar. Jurnal pedagogika dan dinamika pendidikan, 4(1), 17-25. Retrieved from https://ojs3.unpatti.ac.id/index.php/pedagogika/article/view/1643

Mahsun. (2014). Teks dalam pembelajaran bahasa Indonesia kurikulum 2013. Jakarta: Rajawali Pers.

Mayangsari, D dan Umroh, V. (2014). Peran keluarga dalam memotivasi anak usia dini dengan metode quantum learning . Jurnal PG PAUD Trunojoyo, 1(2), 7682.

Retrieved

from https://journal.trunojoyo.ac.id/pgpaudtrunojoyo/article/view/3550

Moleong, L. J. (2015). Metodologi penelitian kualitatif. Bandung: Remaja rosdakarya. Nabillah, C. I. (2020). Tekun berbahasa Indonesia. Sukabumi: Farha pustaka.

Nata, A. (2012). Manajemen pendidikan-mengatasi kelemahan pendidikan islam Indonesia. Surakarta: Kencana.

Osmimi. (2018). Peningkatan keterampilan menulis teks negosiasi menggunakan model cooperative learning tipe CIRC kelas X IPS SMA Negeri 4 Bukittinggi. Jurnal akrab juara, 3(3), 158-165. Retrieved from http://www.akrabjuara.com/index.php/akrabjuara/article/view/325

Patonah, S., Syahrullah, A., Firmansyah, D., dan Fauziya, D. S. (2018). Pengaruh model pembelajaran berbasis masalah (problem based learning) pada pembelajaran menulis teks negosiasi di kelas X SMK Lentera Bangsa. Jurnal pendidikan bahasa dan sastra Indonesia, 1(5), 807-814. Retrieved from https://pdfs.semanticscholar.org/ed02/bc2dc2555c576b0422159b661b0cfe867 c66.pdf 
Pratiwi, W.E.S. (2018). Kemampuan siswa kelas VIII B SMPN Negeri 1 Torue dalam menulis teks berita. Jurnal bahasa dan sastra, 3(4), 1-11. Retrieved from http://jurnal.untad.ac.id/jurnal/index.php/BDS/article/view/10528

Puspaningrum, A., Mahardika, K., dan Supriyadi, B. (2015). Peningkatan kemampuan multirepresentasi IPA (fisika) dengan model quantum learning disertai metode eksperimen pada siswa kelas VIII-A SMP Negeri 7 Jember. Jurnal pendidikan fisika, 3(4), 342-348. Retrieved from https://jurnal.unej.ac.id/index.php/JPF/article/view/1429

Rahman, A.S. (2017). Peningkatan kemampuan menulis naskah drama dengan pendekatan contextual teaching learning (CTL) penelitian tindakan kelas VIII mts. (X) kota Bogor. Jurnal ilmiah pend. bahasa, sastra Indonesia dan daerah, $7(1)$, 32-40. Retrieved from http://journal.unpas.ac.id/index.php/literasi/article/view/276

Rahman, T. (2018). Teks dalam kajian struktur dan kebahasaan. Semarang: Pilar Nusantara.

Riyanto, A. (2018). Hukum bisnis Indonesia. Kepulauan Riau: Batam publisher.

Risdiana, Y. (2016). Penafsiran kontrak komersial antara teks dan konteks. Bandung: Inboeku media ilmu.

Septiaji, A. (2017). Pemanfaatan media audiovisual dalam pembelajaran menulis puisi. Semantik, 4(2), 67-82. Retrieved from http://www.ejournal.stkipsiliwangi.ac.id/index.php/semantik/article/download/454/323

Sugiyono.(2015). Memahami penelitian kualitatif. Bandung: Alfabeta.

Sutarno. (2019). Cermat berbahasa Indonesia suplemen materi bahasa Indonesia untuk kelas $x$. Jawa Barat: Jejak.

Tarmuji, A. (2009). Analisa negosiasi antaragen dalam simulasi transaksi jual-beli barang elektronik menggunakan ciagent framework. Jurnal informatika, 3(1), 248-267. Retrieved from https://www.neliti.com/publications/103786/analisanegosiasi-antaragen-dalam-simulasi-transaksi-jual-beli-barang-elektronik

Tirtoni, F. (2015). Penerapan metode quantum learning berkarakter pada pembelajaran pendidikan kewarganegaraan ( $\mathrm{PKn}$ ) siswa kelas VI A SD AlFalah Tropodo. Jurnal pedagogia, 4(2), 161-167. Retrieved from http://ojs.umsida.ac.id/index.php/pedagogia/article/view/19

Wibowo, B. (2011). Sukses hidup sehari-hari dengan 50 taktik negosiasi.Jakarta:

Elex media kompurindo. 
47 | Penerapan Metode Quantum...

Tabasa: Jurnal Bahasa, Sastra Indonesia, dan Pengajarannya

Vol. 1, No. 1, Juni 2020 